\title{
FACTORS INFLUENCING PURCHASE OF TWO WHEELER - A STUDY WITH REFERNCE TO CHENNAI CITY
}

\author{
S. Diwakar Raj \\ Area Sales Manager, Royal Enfield (A Unit of Eicher Motors Ltd.), Chennai. \\ Research Scholar, Sathyabama Institution of Science and Technology \\ (Deemed to be University), Chennai, Tamilnadu, India \\ Dr. N. Kannan \\ Research Supervisor, Sathyabama Institution of Science and Technology \\ (Deemed to be University) Chennai, Tamilnadu, India
}

\begin{abstract}
The present study is consumer-oriented in nature, pertaining to the preference of the consumers in Chennai City. It focusses on certain objectives and based on survey method. The main purpose of the study is to know the Factors Influencing the Purchase the Two-Wheeler and Expectation of the Consumers in Purchase of Two wheeler.

Majority of the consumers prefer comfort, good after sales service, and smooth suspension. Based on these factors, consumers prefer the two wheelers. So, it is suggested from the research survey that the companies should often conduct a research survey to know the consumers' preferences. If the companies identify the preference factors, they can easily compete, and also improve their sales.
\end{abstract}

Key words: Purchase, Factors, Influence, Two Wheeler

Cite this Article: S. Diwakar Raj and N. Kannan, Factors Influencing Purchase of Two Wheeler - A Study with Reference to Chennai City, International Journal of Management, 11(12), 2020, pp 2977-2982.

http://iaeme.com/Home/issue/IJM?Volume $=11 \&$ Issue $=12$

\section{INTRODUCTION}

India's automotive sector is one of the country's largest beneficiaries of foreign direct investment and accounts for approximately 8 percent of the economy. Not only this industry gaining ground as a global hub of production; world-leading brands are involving actively in local operations to tap towards India's pleasing domestic market.

India has overtaken China to materialize the world's leading market for two-wheelers. A sum of 17.7 million two-wheelers were sold here preceding year, that's over 48,000 units every day. Indian two wheeler production is as old as 53 years. Until the middle of 80 's there were 
only three major motorbike producers in India namely Rajdoot, Escorts and Enfield. The twowheeler industry is perhaps mainly occurring place in terms of new models launched, upgraded products and innovative marketing techniques. Today the Indian two-wheeler markets in highly aggressive the numerous companies who offer anything and everything that a consumer demands and that too at reasonable price. The Indian two-wheeler industry is conquered by three players, Bajaj, Honda and TVS Suzuki, who account for 80 percent of the total twowheeler market. The industry can be divided in to three broad segments: scooters, motorcycles and mopeds.

Transport is an important aid for better hiring. Two - wheelers are becoming more popular especially among the people belonging to middle income group. There is wide choice of brands there is a stiff competition among the manufacturers and marketers to attract the attention of buyers. People prefer a specific model of motorcycle among different brands for various reasons like price, maintenance, fuel efficiency appearance, durability and resale value.

Today the two wheeler industry plays a significant role in the Indian economy. India is the second largest manufactures of two - wheelers in the world. One of the very important characteristics of economic development is the transformation of luxury goods into necessary goods. In recent time one such goods, which has been highly demanded by the customers, is the motor cycle possessing a mechanical device for conveyance is an indicator of good standard of living. Hence an attempt to be made on the Brand Preference of Two-Wheelers Problems and Satisfaction of consumers.

\section{REVIEW OF LITERATURE}

M. Arutselvi (2011), in her paper entitled on, "A study on customer satisfaction towards TVS Bikes" in kanchipuram town, it has examined that the performance of SARADAS Auto Agencies for retaining the customers by their approved sales. The study has used descriptive research method and has adopted survey method for data collection. A sample of 130 respondents has been occupied for this study. The study has concluded that the sales of Saradas Auto Agencies for TVS two wheelers were superior because of the right approach of the group of genuine mechanics.

Bijapurkar, Rama. (2013) Explores the field of consumerism in India and the strategies that are developed to satisfy the consumer. In this book, the author discussed about the surroundings in which consumers survive; the way they believe, their heterogeneous nature and their transformation. India being an rising market in the world, there are a lot of business opportunities. The author tries to educate the readers how to be ready to grasp these opportunities and use them. As an overall result of different changes, India is now in the third decade after liberalization. And he mentioned the structure of consumption and behavior of consumers in his book.

Vijay, Kumar M; Chandra, Basha and Chand,S. (2015) Price is arguably the most vital and important influence on the positioning of the product and its growth and hence has a direct impact on the volume of the sale of the product and share in the market. If put to the right and thoughtful use, effective pricing can earn a business organization a major and sustained share in a given market. A marketing manager can also maintain resale price of his product, maximize profit and achieve the targeted return on investment. As we know, price of any product can directly influence the demand factor and other factors of production of a product directly. Price fixation of any product is not simple and it depends upon several factors like product cost, availability of substitutes, demand, market share, and geographic factors and so on. Keeping the fixation of price of a product in view, the manufacturer has to think over the price of the product at four levels .i.e. reasonable price, high price, low price and resale value of the product. 
Rajesh Mahrotra 2012 found that mileage and engine power are the important factors which affects the buying behaviour, while consumers are not bothered about price.

Abdul Karim B.A. 2012 observed that comfort and convenience is the driving force for the purchase of two wheeler. The study noted that over crowd is the major reason for avoiding the public transport.

Chandok (2005) the television medium is the most attractive and important place to advice. Most of the young people remain glued to the television and enjoy what they see. As a wide range of products and services are consumed or used by children, many companies to target them.

ParmodPathak, Saumya Singh (2004) reviewed about " What dose a consumer want from a Bike" Dubey J and Patel R reviewed about "Role of Advertisement: in buying decision of bikes."

\section{OBJECTIVES}

- To analyse the Age of the Respondents

- To identify the type of Media Created Awareness among the Consumers

- To analyse the Factors Influencing the Purchase the Two-Wheeler

- To know the Expectation of the Consumers in Purchase of Two wheeler

\section{METHODOLOGY}

This study is based on both primary and secondary data. The primary data have been collected from the owners of two -wheelers using questionnaire. The secondary data have been collected from the published reports, records, books, Journals, bulletins, magazines, internet and newspapers. Both the primary data and secondary data have been analysed by using the SPSS package. This study is confined to Chennai Metropolitan with 100 Sample respondents selected adopting Most convenient sampling method.

\section{ANALYSIS AND INTERPRETATION}

Table 1 Age Group of the Respondents

\begin{tabular}{|l|c|c|}
\hline \multicolumn{1}{|c|}{ Age } & No of Respondents & Percentage \\
\hline $20-30 \mathrm{yrs}$ & 52 & 52 \\
\hline $31-40 \mathrm{yrs}$ & 22 & 22 \\
\hline $41-50 \mathrm{yrs}$ & 14 & 14 \\
\hline Above-50yrs & 12 & 12 \\
\hline Total & 100 & 100 \\
\hline
\end{tabular}

Source: Primary data

The above table exhibits that $52 \%$ of the respondents are in the age group of $20-30$ years, $22 \%$ of the respondents are in the age group of $31-40,14 \%$ of the respondents are in the age group of $41-50$, and $12 \%$ of the respondents are in the age group of above 50 . It is concluded that majority of the respondents are in the age group of 20-30 years. 
Factors Influencing Purchase of Two Wheeler - A Study with Reference to Chennai City

Table 2 Type of Media Created Awareness among the Consumers

\begin{tabular}{|l|c|c|}
\hline \multicolumn{1}{|c|}{ Source } & No of Respondents & Percentage \\
\hline Newspaper/Magazine & 21 & 21 \\
\hline T.V/Radio/Cinema Slide & 14 & 14 \\
\hline Friends/Relative & 21 & 21 \\
\hline Auto Consultants & 14 & 14 \\
\hline Radio shows & 9 & 9 \\
\hline Dealers & 7 & 7 \\
\hline Internet & 6 & 6 \\
\hline Others & 8 & 8 \\
\hline Total & 100 & 100 \\
\hline
\end{tabular}

Source: Primary data

The table reveals that $21 \%$ of the respondents have come to know about the brands through their friends and relatives, $14 \%$ of the respondents the product from T.V. / Radio/Cinema slide and dealers respectively. $21 \%$ respondents have stated that news paper/Magazine is the source which created awareness among them. Only a meager percentage i.e. less than $15 \%$ has revealed that they had got awareness through road shows and internet.

Table. 3. Factors Influencing the Purchase the Two-Wheeler

\begin{tabular}{|l|c|c|}
\hline \multicolumn{1}{|c|}{ Factors } & No of Respondents & Percentage \\
\hline Price & 16 & 16 \\
\hline Fuel efficiency & 11 & 11 \\
\hline Product quality & 9 & 9 \\
\hline Gearless transmission & 5 & 5 \\
\hline Exchange Offers & 5 & 5 \\
\hline Installment payment facilities & 7 & 7 \\
\hline Comfort & 6 & 6 \\
\hline Guarantee & 5 & 5 \\
\hline Least problems & 4 & 4 \\
\hline Performance and design & 6 & 6 \\
\hline Resale value & 0 & 0 \\
\hline After sales service & 2 & 2 \\
\hline Smooth suspension & 13 & 13 \\
\hline Brand image & 11 & 11 \\
\hline Total & 100 & 100 \\
\hline
\end{tabular}

Source: Primary data

The table shows that $16 \%$ of the respondents are motivated by price, $11 \%$ of them are motivated by fuel efficiency, $9 \%$ of them are motivated by product quality, $5 \%$ of them are motivated by gearless transmission, $5 \%$ of them are motivated by exchange offer, $7 \%$ of them are motivated by installment payment facility, $6 \%$ of them are motivated by comfort, $5 \%$ of them are motivated by guarantee, and $4 \%$ of them are motivated by least problems. $6 \%, 2 \%$, $13 \%, 11 \%$ of the total respondents have expressed that they are motivated by performance and design, After-sales service, smooth suspension and Brand image respectively. 
Table 4 Expectation of the Consumers

\begin{tabular}{|l|c|c|}
\hline \multicolumn{1}{|c|}{ Facilities } & No. of respondents & Percentage \\
\hline Discount & 15 & 15 \\
\hline Better Service & 58 & 58 \\
\hline Reasonable delivery time & 19 & 19 \\
\hline Any free Gift others & 8 & 8 \\
\hline Total & 100 & 100 \\
\hline
\end{tabular}

Source: Primary data

Now-a-days manufacturers/dealers offer discounts, free-gifts to attract the consumers. Hence, the consumers were asked to mention what type of facility/facilities they expect from the dealer/ manufacturer. The responses of the consumers in the table, It show that, $15.0 \%$ of the consumers expect discount, $58.0 \%$ of the consumers expect better service, $19.0 \%$ of them expect reasonable delivery time and $8.0 \%$ of them expect other facilities. So, majority of the respondents expect better service.

\section{SUGGESTION}

The present study is an attempt to know the preference of the consumers to select two wheelers. The survey reports some useful findings. On the basis of the findings, the following suggestions are arrived at.

The consumers are expecting quality and fuel efficiency. So, the companies have to take steps to improve fuel efficiency. Fuel efficiency is a very important factor for two-wheelers. Majority of the consumers are more aware of this one. Therefore, regarding this aspect, companies design fuel-efficient vehicles. This will create positive attitude to the consumers. From that, companies have to increase their market potential. So, this is also one of the factors, the companies have to concentrate.

Majority of the consumers prefer comfort, good after sales service, and smooth suspension. Based on these factors, consumers prefer the two wheelers. So, it is suggested from the research survey that the companies should often conduct a research survey to know the consumers' preferences. If the companies identify the preference factors, they can easily compete, and also improve their sales.

\section{CONCLUSION}

Transportation needs are becoming more and more acute. With the mounting pressure on the public transportation system, the best available solution is to have personal transportation for which two wheelers are ideal. Therefore, the two wheeler manufacturers should manufacturer their products suited to the needs/preferences of the consumers. In simple terms the fortunes of many a producer will be decided by the emerging consumer preferences for vehicles offering high fuel economy and low maintenance. The suggestions given in the paper would help the manufacturers to produce the two wheelers in accordance with the preferences of the consumers.

\section{REFERENCES}

[1] Abdul Karim B.A. (2012), Asian Journal of Research in Business Economic and Management, Vol.III, No.3. "A Study of Two Wheelers Consumer Buyer Behaviour in Tirunelveli City."

[2] An Empirical learning of Buying Behaviour of the Two Wheeler users in Jaipur District, Asian Journal of Research in Business Economic and Management, Rajesh Mahrotra, Vol.I, No.5. pp.24-35. (2012), 
[3] Chandok Anil (2005) "Impact of Advertsing on Children's Buying Behavior" Marketing in this regard and their work was published in Paradigm, Vol.VIII No. 1 January- June 2004.

[4] James L. Heskelt, "Marketing A Behavioural Analysis", MC Craw Hill Book Company, England, 1975.

[5] John A. Howard and Jagdish N, "The Theory of Buyer Behaviour", New York, 1969.

[6] Kotler Philp, "Marketing Management", Analysis planning control practice Hall of India Pvt. Ltd.,1986.

[7] Parmod Pathak, Saumya Singh (2004) Brand Preference of Two Wheelers - (A Study with Special Reference to Bajaj Two Wheeler Users inSalem District) Volume 02, Issue 03, Version I, Jul - Sep' 201564 Mastermind. Pp.41-46.

[8] Sherlekar S.A, "Modern Marketing Principles and Practices", Himalaya Publishing House, Bombay, 1997. 